\title{
Profesor Stanisław Wieteska - naukowiec, dydaktyk, organizator, kolega
}

\author{
Andrzej Borowicz \\ dr hab. prof. nadzw. UŁ, Katedra Inwestycji i Nieruchomości, \\ Wydział Ekonomiczno-Socjologiczny, \\ Uniwersytet Łódzki \\ Eugeniusz Wojciechowski \\ prof. zw. dr hab., Katedra Gospodarki Samorządu Terytorialnego, \\ Wydział Ekonomiczno-Socjologiczny, \\ Uniwersytet Łódzki
}

Profesor Stanisław Wieteska jest osobą wyjątkową, która szczególnie umiejętnie potrafiła połączyć efektywną działalność akademicką, zarówno naukową jak i dydaktyczno-organizacyjną, z owocnymi kontaktami z praktyką gospodarczą.

Po habilitacji Profesor Stanisław Wieteska zajął się w sposób pionierski bardzo istotnymi problemami rynku ubezpieczeń, wypracowując w tym zakresie dorobek o fundamentalnym znaczeniu. Niezależnie od wieloletniej aktywności naukowej, Profesor cały czas był wspaniałym kolegą i ojcem rodziny, którego rzadko spotykaną witalność i kreatywność mieliśmy okazję obserwować i podziwiać, jak dotąd, przez blisko pół wieku.

\section{Kalendarium kariery akademickiej}

W kalendarium kariery naukowej Profesora Stanisława Wieteski wyróżnić należy pięć następujących dat:

- 1972 - magisterium z ekonomii,

- 1982 - magisterium z matematyki,

- 1977 - doktorat z ekonomii,

- 1987 - habilitacja w zakresie nauk ekonomicznych,

- 2007 - profesura tytularna. 
Tytuł rozprawy habilitacyjnej nie wskazywał jeszcze na fakt, że podstawową domeną dorobku naukowego Profesora stanie się teoria i praktyka ubezpieczeń. Brzmiał on bowiem: Ekonomiczne aspekty zużcia budynków mieszkalnych.

\section{Współpraca z praktyką gospodarczą}

Wątek współpracy z praktyką gospodarczą eksponujemy dlatego, że sam Profesor szczególnie wysoko ceni sobie doświadczenia zdobyte w jej efekcie.

Współpraca ta została zapoczątkowana w roku 1990, kiedy to Profesor Stanisław Wieteska podjął pracę w Zakładzie Ubezpieczeniowym „Westa”, a od 1993 roku - w Towarzystwie Ubezpieczeń i Reasekuracji „Polonia”. W obu tych Towarzystwach Profesor Stanisław Wieteska pracował w dziale aktuarialnym. Doświadczenia zdobyte w tym dziale obecnie, z perspektywy czasu, Profesor ceni sobie szczególnie.

W obu Towarzystwach Profesor zajmował się kalkulacją rezerw techniczno-ubezpieczeniowych, marginesu wypłacalności oraz taryf ubezpieczeniowych, jak również opracowywaniem nowych produktów ubezpieczeniowych. Zrealizował także szereg analiz ekonomicznych dotyczących problemów ubezpieczeń.

W roku 2001 Towarzystwo Ubezpieczeniowe „Polonia” zostało przejęte przez Towarzystwo Ubezpieczeniowe Uniqua S.A. W tym ostatnim Towarzystwie Profesor pracował do końca roku 2003.

W ciągu 13 lat pracy w zakładach ubezpieczeniowych Profesor Stanisław Wieteska zdobył, jak sam stwierdza, istotne doświadczenie w zakresie praktyki ubezpieczeń majątkowo-osobowych, które umożliwiło $\mathrm{Mu}$ nowe spojrzenie na teorię ubezpieczeń.

\section{Zainteresowania naukowo-badawcze}

W latach 1973-1992 zainteresowania naukowe Profesora Stanisława Wieteski koncentrowały się na gospodarce mieszkaniowej, w szczególności na eksploatacji budynków mieszkalnych.

Od roku 1993 skupiają się one natomiast na, rozumianej szeroko, problematyce ubezpieczeniowej, w tym zwłaszcza na: ekonomice ubezpieczeń, rachunku świadczeń emerytalnych, ubezpieczeniach majątkowo- 
-osobowych, teorii ryzyka ubezpieczeniowego, demografii matematycznej, matematyce finansowej oraz rachunku aktuarialnym.

W zakresie problematyki ubezpieczeniowej Profesor Stanisław Wieteska jest obecnie niekwestionowanym i powszechnie uznawanym autorytetem naukowym, co wyraźnie potwierdza analiza Jego bogatego dorobku naukowego, którego istotną częścią są liczne recenzje prac awansowych oraz opracowań i projektów naukowych.

\section{Współpraca z innymi Uczelniami}

O wysokiej pozycji naukowej Profesora Stanisława Wieteski świadczy również fakt, jak wiele Uczelni było zainteresowanych podjęciem z Nim współpracy. Tak więc, oprócz macierzystego Uniwersytetu Łódzkiego, były to następujące uczelnie:

- Uniwersytet im. Jana Kochanowskiego w Kielcach, Filia w Piotrkowie Trybunalskim, gdzie Profesor jest zatrudniony od 2005 roku do chwili obecnej,

- Wyższa Szkoła Bankowości, Finansów i Ubezpieczeń im. J Chechlińskiego w Łodzi, z którą Profesor współpracował w latach 1994-2004,

- Salezjańska Szkoła Ekonomii i Zarządzania w Łodzi (1996-2004),

- Wyższa Szkoła Kupiecka w Łodzi (1996-2003) oraz

- Wyższa Szkoła Zarządzania w Łodzi (1998-2000).

Profesor w latach 1996-2005 prowadził ponadto wykłady na Podyplomowym Studium Prawa Ubezpieczeń Społecznych na Wydziale Prawa i Administracji Uniwersytetu Łódzkiego.

\section{Dorobek publikacyjny Profesora}

Dotychczasowy dorobek publikacyjny Profesora jest obszerny i bogaty, zarówno pod względem jakościowym, jak i ilościowym.

\section{Charakterystyka jakościowa dorobku naukowego}

Spektrum badań, które znalazły swoje odzwierciedlenie w publikacjach naukowych Profesora Stanisława Wieteski, jest bardzo szerokie. Przedmiotem tych prac były w szczególności takie zagadnienia, jak: 
- rola zakładów ubezpieczeń w zrównoważonym rozwoju,

- zagrożenia naturalne,

- obowiązkowe ubezpieczenia OC,

- metody kalkulacji składek ubezpieczeniowych,

- etyka ubezpieczeniowa.

Profesor opracował także wiele nowych produktów ubezpieczeniowych, stanowiących odpowiedź na ciągle zmieniające się zapotrzebowanie na usługi ubezpieczeniowe w naszym kraju.

Dorobek publikacyjny Profesora Stanisława Wieteski, ze względu zarówno na jego wysoki poziom naukowy, jak również kluczowe znaczenie podejmowanych problemów, w sposób istotny przyczynił się do rozwoju zarówno teorii, jak i praktyki ubezpieczeń w Polsce.

\section{Charakterystyka ilościowa dorobku naukowego}

W ujęciu kwantytatywnym dorobek naukowy Profesora Stanisława Wieteski przedstawia się również imponująco. Obejmuje on bowiem, jedynie od roku 2004, ponad 80 publikacji artykułowych oraz rozdziałów w monografiach naukowych.

Do znaczących opracowań monograficznych, których autorem jest Profesor Stanisław Wieteska, należy zaliczyć następujące publikacje:

- Zbiór zadań z matematycznej teorii ryzyka ubezpieczeniowego, $\mathrm{Wy}-$ dawnictwo Uniwersytetu Łódzkiego, Łódź 2001,

- Rezerwy techniczno-ubezpieczeniowe zakładów ubezpieczeń majątkowo-osobowych. Teoria i praktyka, Oficyna Wydawnicza Branta, Bydgoszcz-Łódź 2004,

- Zagrożenia naturalne w polskim obszarze terytorialnym. Praktyczne podstawy do kalkulacji składek ubezpieczeń majątkowo-osobowych, Naukowe Wydawnictwo Piotrkowskie, Piotrków Trybunalski 2015.

Dorobek Profesora Stanisława Wieteski zostanie niebawem w sposób bardzo istotny powiększony. Na liście prac naukowych Profesora, które przyjęte zostały do druku znajduje się bowiem aktualnie 18 pozycji, natomiast w przegotowaniu jest 26 dalszych artykułów naukowych.

\section{Udział w życiu naukowym}

Istotnym wyróżnikiem rangi uczonego jest ilość recenzji, o które był On proszony. Również i ta miara pozycjonuje Profesora Stanisława Wieteskę bardzo wysoko. Jego dorobek recenzencki, jedynie od 2004 roku, 
obejmuje po dwie recenzje profesorskie, habilitacyjne i dorobku habilitantów, sześć recenzji prac doktorskich oraz czteyu recenzje wydawnicze monografii. Ponadto Profesor sporządził wiele opinii, zarówno na zlecenie KBN, jak i NCN oraz kilkadziesiąt recenzji artykułów na kanwie referatów wygłaszanych na konferencjach naukowych organizowanych przez różne ośrodki akademickie w kraju.

\section{Kształcenie kadry naukowej}

Do chwili obecnej Profesor Stanisław Wieteska wypromował pięciu doktorów. Ponadto aktualnie Profesor jest promotorem kolejnych trzech prac doktorskich, dla których zostały już otwarte przewody. Są to prace:

- Anety Tomaszkiewicz, Adekwatność sum ubezpieczenia w ubezpieczeniach nieruchomości mieszkalnych $w$ Łodzi,

- Darii Korytkowskiej, Finansowe skutki wystepowania szkód na pacjentach na przykładzie szpitali okręgu łódzkiego w latach 2005-2010,

- Joanny Mrozowicz, Bezpośrednie szkody popowodziowe w gospodarstwach domowych na przykładzie Sandomierza.

Tematyka prac doktorskich przygotowywanych i obronionych pod kierunkiem Profesora Stanisława Wieteski świadczą o Jego niebagatelnym wkładzie $\mathrm{w}$ proces kształcenia wysoko kwalifikowanych kadr dla sektora ubezpieczeń.

\section{Udział w programach badawczych}

Profesor Stanisław Wieteska brał aktywny udział w realizacji programów badawczych. Przykładowymi projektami badawczymi, w których Profesor uczestniczył jako wykonawca lub podwykonawca są:

- Wspótpraca sektora bankowego i ubezpieczeniowego ze szczególnym uwzględnieniem ubezpieczenia kredytu (2001-2002),

- Efektywność ekonomiczna działalności lokacyjnej zakładów ubezpieczeń w Polsce w latach 1995-2002 (projekt KBN, 2003-2005),

- Determinanty i implikacje pracy na własny rachunek w polskiej gospodarce (podwykonawca, projekt KBN, 2003-2005). 


\section{Udział w konferencjach}

W latach 2001-2016 Profesor Stanisław Wieteska aktywnie uczestniczył w 76 konferencjach naukowych organizowanych przez różne ośrodki akademickie.

Od roku 2014 Profesor bierze aktywny udział m.in. w konferencjach naukowych organizowanych przez Wyższą Szkołę Bezpieczeństwa w Poznaniu, na których wygłosił 5 referatów naukowych, następnie opublikowanych w materiałach konferencyjnych.

\section{Dorobek organizacyjny}

W bogatym dorobku organizacyjnym Profesora na szczególne wyróżnienie zasługuje:

- powołanie specjalności „Ubezpieczenia” na Wydziale EkonomicznoSocjologicznym Uniwersytetu Łódzkiego z oryginalnym, autorskim programemkształcenia oraz pełnieniefunkcjiopiekuna tej specjalności,

- od 1.10.2000 do 30.09.2016 roku - kierowanie Katedrą Ubezpieczeń na Wydziale Ekonomiczno-Socjologicznym Uniwersytetu Łódzkiego,

- wielokrotny udział w komisjach zadaniowych powoływanych na Wydziale Ekonomiczno-Socjologicznym Uniwersytetu Łódzkiego.

\section{Nagrody}

Za swoją działalność naukowo-badawczą Profesor Stanisław Wieteska został wyróżniony ośmioma nagrodami Rektora Uniwersytetu Łódzkiego, w tym:

- w 2009 roku nagrodą Rektora UŁ II ${ }^{\circ}$ za osiągnięcia naukowe. Podstawa: cykl publikacji z zakresu teorii i praktyki ubezpieczeń,

- w 2011 roku nagrodą Rektora UŁ III za osiągnięcia naukowe. Podstawa: cykl publikacji na temat szerokiego spectrum problemów ubezpieczeniowych. 


\section{Inne szczególne osiągnięcia Profesora}

Profesor Stanisław Wieteska był jak dotąd promotorem ponad 500 prac licencjackich i magisterskich. Niektóre $\mathrm{z}$ tych prac zostały dostrzeżone przez różne instytucje oraz stowarzyszenia. Sześć prac uzyskało nagrody Rzecznika Ubezpieczonych. Jedna nich została także uhonorowana nagrodą Polskiego Towarzystwa Kryminalistycznego, inna natomiast została wdrożona i opublikowana przez Towarzystwo Ubezpieczeń i Reasekuracji WARTA. Napisana pod kierunkiem Profesora Stanisława Wieteski praca doktorska Pani Kingi Stęplewskiej Czynniki kształtujące decyzje klientów rynku ubezpieczeń na życie w woj. świętokrzyskim (Łódź 2011) uzyskała Nagrodę III ${ }^{\circ}$ Rzecznika Ubezpieczonych oraz Nagrodę Stowarzyszenia Oceny Ryzyka i Likwidacji Szkód w Kielcach.

Szczególnym wyrazem uznania dla Profesora Stanisława Wieteski jest głęboki szacunek $i$ podziw zarówno wspótpracowników, jak i koleżanek i kolegów z Wydziału Ekonomiczno-Socjologicznego UŁ, którzy przez wiele lat mieli okazję obserwować Jego energię, wytrwałość i konsekwencję badawcza oraz spontaniczna pracowitość. Nade wszystko jednak nas, jako wieloletnich kolegów Profesora poczynając od okresu studiów, zawsze uderzała Jego koleżeńskość $i$ życzliwość przejawiana we wszystkich sytuacjach, w których przyszło się nam razem znaleźć.

Bez watpienia Profesor Stanisław Wieteska jest uznanym autorytetem, nie tylko w naszym środowisku naukowym, ale również we wszystkich liczacych się ośrodkach akademickich w Polsce. 